\title{
HAEMODYNAMICS AND RENAL FUNCTION DURING ADMINISTRATION OF LOW DOSE DOPAMINE IN CRITICALLY ILL PATIENTS
}

Tayser Mohamed Zaytoun, Sherif Ahmed Abdel-moniem, Adham Gamal Kotb

Department of critical care, Alexandria University, Faculty of Medicine, Alexandria University, Egypt

\section{INTROdUction}

The kidneys possess a dopaminergic system that seems to be independent fom neural dopamine systems. Due to the actions of dopamine on the rom neural dopamine systems. Due to the actions of dopamine on the adrenergic), dopamine represents a key drug in the regulation of blood pressure levels in patients with hemodynamic instability and hypotension. Stimulation of dopamine in D1-like and D2-like receptors induces natriuresis, diuresis, and improvement of renal blood flow through vasodilation (preferably of the afferent renal arteriole). For this reason, dopamine is used at low levels to promote diuresis and at high pressure.

\section{Alim of thes work}

To evaluate the effects of dopamine $(2 \mathrm{mg} / \mathrm{kg} / \mathrm{min})$ on systemic hemodynamics (heart rate, HR, central venous pressure, CVP), creatinine clearance (CLCr), diuresis and fractional sodium excretion (FENa ${ }^{+}$) in clearance (CLCr), diuresis comparison with Fursoemide.

\section{PATIIENTSS}

This multi-centered study will be carried out over a period of four months a critical care units in Alexandria university hospitals.

Approval of the Medical Ethics Committee of Alexandria Faculty of Medicine. An informed consent will be taken from the patients' next of kin befre enrollment in the study.

Exclusion criteria: Patients aged below 18 years, Patient with severe pulmonary hypertension, ESRD patients on Haemodialysis, AKI due tc obstructive uropathy, Toxin induced AKI, Chronic AF patients and Patients with contraindications for bladder catheterization

\section{MEthods}

Patients were evaluated over a 24-hour period divided into two groups. In the First group (G1), $2 \mathrm{~g} / \mathrm{kg} / \mathrm{min}$ of dopamine were administered. In the second group (G2), Furosemide infusion at a rate of $20 \mathrm{mg} / \mathrm{hr}$ were administerd.At the end of each period, diuresis (UV) was established and the following were measured,Urinary sodium (UNa+-mmol/I), Urinary creatinine (UCr, $\mathrm{mmol} / \mathrm{l})$, Plasma sodium ( $\mathrm{PNa}+, \mathrm{mmol} / \mathrm{l}$ )and Plasma creatinine ( $\mathrm{PCr}, \mathrm{mol} / \mathrm{I})$ From the data obtained above, the creatinine clearance ( $\mathrm{CLCr}=U \mathrm{Ur} / \mathrm{PCr} \times \mathrm{UV}$ ) and the fractional sodium urinary excretion $(\mathrm{FENa}+=\mathrm{UNa}+\mathrm{x} \mathrm{PCr} / \mathrm{PNa}+\mathrm{x} \mathrm{UCr}$ ) were calculated.

\section{REsultis}

We have shown that the infusion of $2 \mathrm{mg} / \mathrm{kg} / \mathrm{min}$ of dopamine for 24 hours increased the diuresis significantly but still Fursoemide achieved slightly better UOP. Also ,our study showed that LDD has a notable impact on CLC ,even better then furosemide especially in sepsis patients, where it was demonstrated that UV clearance before administration of dopamine ranged from $40.0-94$ (1) $\pm 19.16 \mathrm{ml} / \mathrm{min}$ and Percent change of UV clearance in dopamine group ranged from $-12.82-100.0$ in sepsis group with median of 22.22 , while ranged from $-8.33-25.81$ in other causes of AKI with median of -3.80 . This is in agreement with many other studies on humans.

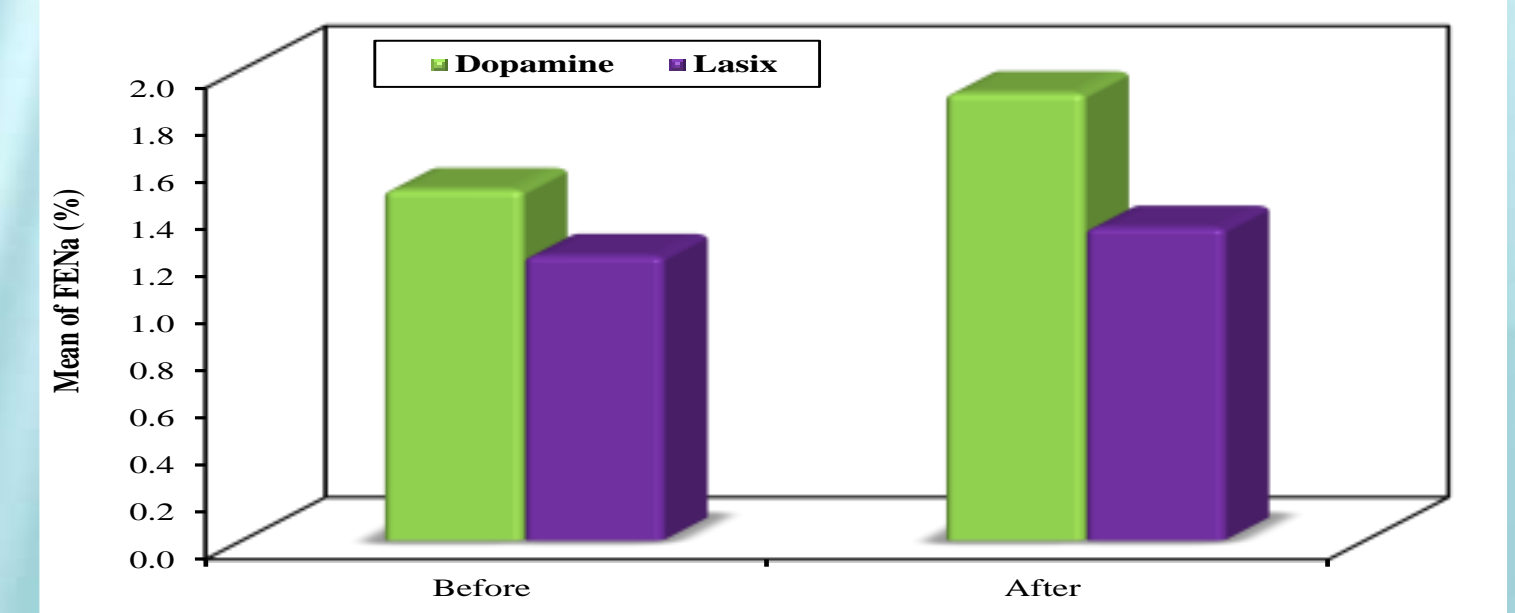

Figure (1): Comparison between the two studied groups according to UV CL
Table (1): Comparison between the two studied groups according to UV CL

\begin{tabular}{||l|c|c|c||}
\hline \hline \multicolumn{1}{|c|}{ UV CL } & $\begin{array}{c}\text { Dopamine } \\
(\mathbf{n = 4 0 )}\end{array}$ & $\begin{array}{c}\text { Lasix } \\
(\mathbf{n = 4 0 )}\end{array}$ & $\mathbf{p}$ \\
\hline Before & $40.0-94.0$ & $60.0-96.0$ & \\
Min.-Max. & $78.15 \pm 16.79$ & $80.13 \pm 10.47$ & 0.530 \\
Mean \pm SD. & & & \\
\hline After & $50.0-117.0$ & $50.0-118.0$ & 0.196 \\
Min.- Max. & $87.80 \pm 19.16$ & $82.63 \pm 16.23$ & \\
Mean \pm SD. & $<0.001^{*}$ & $<0.001^{*}$ & \\
\hline \multicolumn{1}{|c|}{$\mathbf{p}_{1}$} & & & \\
\hline Improvement & $-10.0-40.0$ & $-20.0-25.0$ & 0.144 \\
Min.-Max. & $0.0(0.0-20.0)$ & $0.0(0.0-16.0)$ & \\
Median (IQR) & & & \\
\hline \% of improvement & $-12.82-100.0$ & $-25.0-39.68$ & 0.160 \\
Min.-Max. & $0.0(0.0-24.73)$ & $0.0(0.0-19.35)$ & \\
Median (IQR) & \multicolumn{3}{|l}{} \\
\hline
\end{tabular}

\section{Conclusion}

Infusion of $2 \mathrm{mg} / \mathrm{kg} / \mathrm{min}$ of dopamine for 24 hours in critically ill patien with AKI has a notable impact on increasing their UOP although not as potent Fursoemide,

during the administration of LDD

The use of dopamine for its systemic effects in Sepsis should not be precluded,

LDD infusion has a strong natriuretic effect in comparison to furosemide infusion

$$
\begin{gathered}
\text { 20210Alexandria Faculty of Medicine } \\
\text { CC-BY-NC }
\end{gathered}
$$

MEDICINE $\mid$ ferty 